\title{
Promiscuous words
}

\author{
Mark A Elgar ${ }^{1 *}$, Therésa M Jones ${ }^{1}$ and Kathryn B McNamara ${ }^{2}$
}

\begin{abstract}
Promiscuity is frequently used to describe animal mating behaviour, and especially to describe multiple mating by females. Yet this use of the term is incorrect, perhaps reflecting an erroneous adoption of common language to pique reader interest. We evaluated the patterns of use and misuse of the word 'promiscuity' in a representative journal of animal behaviour. This survey highlights how inappropriately the term is used, and how it can conceal critical features of animal mating strategies with intriguing evolutionary significance. Further analysis of the scientific impact of papers identified by the term promiscuous or polyandrous revealed that the former were cited less frequently. We argue that using promiscuity to describe animal mating strategies is anthropomorphic, inaccurate, and potentially misleading. Consistent with other biological disciplines, the word promiscuity should be used to describe indiscriminate mating behaviour only, and that polygyny and polyandry should be used to describe male and female mating frequency respectively.
\end{abstract}

\section{Introduction}

Promiscuity is frequently, but largely incorrectly used to describe animal mating behaviour, perhaps reflecting an erroneous adoption of common language to pique reader interest. According to The Oxford English Dictionary, promiscuous originally referred to repeated, indiscriminate actions: "That is without discrimination or method: confusedly mingled, indiscriminate (1605) ... Of an agent or agency: making no distinctions: undiscriminating (1633) ... casual, carelessly irregular (1837)" [1]. Promiscuity was used to describe human sexual activity in the $19^{\text {th }}$ Century, the essence (and costs) of which are colourfully observed in George Sala's bawdy pantomime Harlequin Prince Cherrytop (1879): "Better frig, howe'er the mind it shocks, than from promiscuous ... [fornication] ... catch the pox" [2].

The term 'promiscuity' sneaked into the lexicon of evolutionary biology last century, particularly to describe mating behaviour e.g. [3-6] and is now widely entrenched (a Web of Knowledge (Thomson Reuters) search for 'promiscu"', limited to the fields of 'Evolutionary Biology', 'Zoology', 'Behavioural Sciences', and 'Ecology' returned over 700 publications). It is currently typically, although not exclusively [7], applied to describe female multiple mating or polyandry - the latter taking precedent [8].

\footnotetext{
*Correspondence: m.elgar@unimelb.edu.au

'Department of Zoology, University of Melbourne, Melbourne, VIC 3010, Australia

Full list of author information is available at the end of the article
}

Science often borrows words from common language: very early uses of the word promiscuous referred to surgical procedures [9], the use of barbiturates [10] and landscape management [11], and more recently molecular biologists use promiscuous to describe certain enzymes [12], gene regulators [13] and receptors [14] as promiscuous, precisely due to their non-specific nature. The use of these terms as scientific jargon draws on the general meaning of the word to highlight indiscriminating processes. This contrasts with its use as a descriptor for multiple mating behaviour, because the implied indiscriminating mate selection process is broadly wrong.

Females are rarely promiscuous, in the general meaning noted in the Oxford English Dictionary: the overwhelming evidence from diverse taxa confirms Darwin's suggestion [15] that females are typically circumspect about their mates [16], accruing a variety of benefits from their discriminate mating [17,18], including with multiple partners [19]. In general, we expect females to remain choosy, irrespective of the number of mating partners, the exception being species in which there is cryptic female choice e.g. [20].

Promiscuous has been used as an umbrella term to include polyandry, polygyny, and polygynandry [21]. While it may be useful to use a single term to describe mating strategies in which males and females mate multiply (arguably, the modal animal mating behaviour), promiscuous is unhelpful because it conflates both the nature (discriminating or not) and frequency of mating. In contrast, the terms monogamy, polygyny, polyandry and polygynandry 


\begin{tabular}{|c|c|c|c|c|c|c|c|}
\hline & & & & & & & \\
\hline & & Title & Abstract & Text & Key-words & Sex & \\
\hline Models of parent-offspring conflict 2. Promiscuity & 1978, 26:111-122 & Yes & Yes & Yes & No & Female & - \\
\hline $\begin{array}{l}\text { Postcopulatory mate guarding delays promiscuous mating } \\
\text { by female decorated crickets }\end{array}$ & $1994,48: 1479-1481$ & Yes & - & Yes & No & Female & Yes \\
\hline Mate sampling in a population of sand gobies & $1997,53: 267-276$ & No & Yes & Yes & No & Both & Yes \\
\hline $\begin{array}{l}\text { Behavioural correlates of monogamy in the noisy miner, } \\
\text { Manorina melanocephala }\end{array}$ & 1997, 54:571-578 & No & Yes & Yes & No & Female & No \\
\hline $\begin{array}{l}\text { Spawning success in the damselfish Amblyglyphidodon } \\
\text { leucogaster: the influence of eggs in the nest }\end{array}$ & 1998, 55:651-664 & No & Yes & Yes & No & Both & Yes \\
\hline $\begin{array}{l}\text { Behavioural aspects of the raccoon mating system: } \\
\text { determinants of consortship success }\end{array}$ & 1999, 57:593-601 & No & Yes & Yes & No & Female & Yes \\
\hline $\begin{array}{l}\text { Male mating behaviour and sperm production characteristics } \\
\text { under varying sperm competition risk in guppies }\end{array}$ & 1999, 58:1001-1006 & No & Yes & Yes & No & Female & Yes \\
\hline $\begin{array}{l}\text { Effects of body size and home range on access to mates and } \\
\text { paternity in male bridled nailtail wallabies }\end{array}$ & 1999, 58:121-130 & No & Yes & Yes & No & Both & Yes \\
\hline $\begin{array}{l}\text { Proximate factors associated with high levels of extra-consort } \\
\text { fertilization in polygynous grey seals }\end{array}$ & $1999,58: 527-535$ & No & Yes & Yes & No & Female & Yes \\
\hline $\begin{array}{l}\text { Sexual selection and the evolution of exclusive paternal } \\
\text { care in arthropods }\end{array}$ & $2000,60: 559-567$ & No & Yes & Yes & No & Male & - \\
\hline $\begin{array}{l}\text { Lack of parasite-mediated sexual selection in a } \\
\text { ladybird/sexually transmitted disease system }\end{array}$ & 2002, 63:131-141 & No & Yes & Yes & No & Both & No \\
\hline $\begin{array}{l}\text { Sexual selection, multiple mating and paternity in grey } \\
\text { mouse lemurs, Microcebus murinus }\end{array}$ & 2002, 63:259-268 & No & Yes & Yes & No & Both & Yes \\
\hline Genetic monogamy in Monteiro's hornbill, Tockus monteiri & 2002, 63:787-793 & No & Yes & No & No & Female & No \\
\hline $\begin{array}{l}\text { The effects of sexual selection and life history on the genetic } \\
\text { structure of redfronted lemur, Eulemur fulvus rufus, groups }\end{array}$ & $2002,64: 557-568$ & No & Yes & Yes & No & Female & No \\
\hline $\begin{array}{l}\text { Effects of repeated mating and polyandry on the } \\
\text { fecundity, fertility and maternal behaviour of female } \\
\text { earwigs, Euborellia plebeja }\end{array}$ & 2003, 65:205-214 & No & Yes & No & No & Female & No \\
\hline $\begin{array}{l}\text { Spacing behaviour and its implications for the mating system of } \\
\text { a precocial small mammal: an almost asocial cavy Cavia magna? }\end{array}$ & $2003,66: 225-238$ & No & Yes & Yes & No & Female & No \\
\hline Behavioural defenses against sexually transmitted diseases in primates & $2003,66: 37-48$ & No & Yes & Yes & No & Female & - \\
\hline $\begin{array}{l}\text { Extrapair paternity in the common sandpiper, Actitis } \\
\text { hypoleucos, revealed by DNA fingerprinting }\end{array}$ & 2004, 67:333-342 & No & Yes & Yes & No & Female & No \\
\hline $\begin{array}{l}\text { Spacing pattern in a social group of stray cats: effects on } \\
\text { male reproductive success }\end{array}$ & 2004, 68:175-180 & No & Yes & Yes & No & & No \\
\hline Extrapair paternity and offspring immunocompetence in & 2004, 68:283-289 & No & Yes & Yes & No & Female & Yes \\
\hline
\end{tabular}

the reed bunting, Emberiza schoeniclus 
Table 1 Details of papers published in the journal Animal Behaviour that make reference to promiscuity (Continued)

\begin{tabular}{|c|c|c|c|c|c|c|c|}
\hline $\begin{array}{l}\text { Estimates of extreme sperm production: morphological } \\
\text { and experimental evidence from reproductively } \\
\text { promiscuous fairy-wrens (Malurus) }\end{array}$ & $2004,68: 541-550$ & Yes & Yes & Yes & No & Female & Yes \\
\hline $\begin{array}{l}\text { A pair choice test to identify female mating pattern relative } \\
\text { to ovulation in longtailed macaques, Macaca fascicularis }\end{array}$ & 2005, 70:1283-1296 & No & Yes & Yes & No & Female & No \\
\hline Context-dependent male mating preferences for unfamiliar females & 2005, 70:1429-1437 & No & Yes & Yes & No & Male & No \\
\hline $\begin{array}{l}\text { Social modulation of androgens in male vertebrates: } \\
\text { meta-analyses of the challenge hypothesis }\end{array}$ & $2006,71: 265-277$ & No & Yes & Yes & No & Female & - \\
\hline $\begin{array}{l}\text { Number of mates and timing of mating affect offspring } \\
\text { growth in the small marsupial Antechinus agilis }\end{array}$ & 2006, 71:289-297 & No & Yes & Yes & No & Both & Yes \\
\hline $\begin{array}{l}\text { Variation in the cost to females of the sexual conflict } \\
\text { over mating in the seed bug, Lygaeus equestris }\end{array}$ & $2006,72: 313-321$ & No & Yes & Yes & No & Both & No \\
\hline $\begin{array}{l}\text { The impact of lekking on the spatial variation in payoffs } \\
\text { to resource-defending topi bulls, Damaliscus lunatus }\end{array}$ & $2008,75: 1229-1234$ & No & Yes & No & No & Female & Yes \\
\hline $\begin{array}{l}\text { Investment in eggs is influenced by male coloration in } \\
\text { the ostrich, Struthio camelus }\end{array}$ & 2009, 77:1027-1032 & No & Yes & Yes & No & Both & No \\
\hline $\begin{array}{l}\text { Male coloration reveals different components of } \\
\text { immunocompetence in ostriches, Struthio camelus }\end{array}$ & 2009, 77:1033-1039 & No & Yes & Yes & No & Both & Yes \\
\hline $\begin{array}{l}\text { Paternity assurance through frequent copulations in a } \\
\text { wild passerine with intense sperm competition }\end{array}$ & 2009, 77:183-187 & No & Yes & No & No & Female & No \\
\hline $\begin{array}{l}\text { Quantifying and comparing mating systems using } \\
\text { normalized mutual entropy }\end{array}$ & 2009, 77:201-206 & No & Yes & Yes & Yes & Both & - \\
\hline $\begin{array}{l}\text { Do male guppies distinguish virgin females from } \\
\text { recently mated ones? }\end{array}$ & 2009, 77:425-431 & No & Yes & No & No & Female & Yes \\
\hline $\begin{array}{l}\text { Another genetically promiscuous 'polygynous' mammal: } \\
\text { mating system variation in Neotoma fuscipes }\end{array}$ & 2009, 77:449-455 & Yes & Yes & Yes & Yes & Both & No \\
\hline $\begin{array}{l}\text { Male dominance rank and reproductive success in } \\
\text { chimpanzees, Pan troglodytes schweinfurthii }\end{array}$ & 2009, 77:873-885 & No & Yes & Yes & No & Female & Yes \\
\hline $\begin{array}{l}\text { Male feeding rate and extrapair paternity in the } \\
\text { facultatively polygynous spotless starling }\end{array}$ & 2009, 78:1335-1341 & No & Yes & Yes & No & Female & No \\
\hline $\begin{array}{l}\text { Male mate-searching strategies and female cues: how } \\
\text { do male guppies find receptive females? }\end{array}$ & 2010, 79:1191-1197 & No & Yes & Yes & No & Female & Yes \\
\hline $\begin{array}{l}\text { Plumage coloration, ejaculate quality and reproductive } \\
\text { phenotype in the red-backed fairy-wren }\end{array}$ & $2010,79: 1239-1246$ & No & Yes & Yes & No & Female & Yes \\
\hline $\begin{array}{l}\text { Male aggression and sexual coercion in wild West } \\
\text { African chimpanzees, Pan troglodytes verus }\end{array}$ & 2010, 79:333-342 & No & Yes & No & No & Both & Yes \\
\hline $\begin{array}{l}\text { Sperm removal, ejaculation and their behavioural interaction } \\
\text { in male cuttlefish in response to female mating history }\end{array}$ & $2010,79: 613-619$ & No & No & Yes & Yes & Both & No \\
\hline
\end{tabular}

${ }^{1}$ Not included for theoretical or review papers. 
Table 2 Characteristics of papers retrieved by the search term 'promiscuity' or 'promiscuous' and 'polyandry' and 'polyandrous' in 13 journals from 2000 to 31 st July 2013

\begin{tabular}{|c|c|c|c|c|c|c|c|c|c|c|c|}
\hline \multirow[t]{2}{*}{ Journal } & \multirow[t]{2}{*}{$\begin{array}{l}\text { Journal Impact } \\
\text { Factor }^{1}\end{array}$} & \multicolumn{4}{|c|}{$\begin{array}{l}\text { Papers retrieved by the search term } \\
\text { 'Promiscuity' or 'Promiscuous' }\end{array}$} & \multicolumn{4}{|c|}{$\begin{array}{l}\text { Papers retrieved by the search term } \\
\text { 'Polyandry' or 'Polyandrous' }\end{array}$} & \multirow[t]{2}{*}{$\begin{array}{l}\% \text { papers retrieved } \\
\text { by promiscuous }\end{array}$} & \multirow[t]{2}{*}{$\Delta$ cites $^{4}$} \\
\hline & & Papers & $\begin{array}{l}\text { Most cites } \\
\text { in a paper }\end{array}$ & $\begin{array}{l}\text { Mean cites } \\
\text { per paper }\end{array}$ & h-index ${ }^{2}$ & Papers & Most cites in a paper & Mean cites per paper & h-index ${ }^{2}$ & & \\
\hline American Naturalist & 4.55 & 9 & 205 & 43 & 7 & 21 & 118 & 24 & 13 & 30.0 & 19 \\
\hline Animal Behaviour & 3.07 & 39 & 118 & 15 & 14 & 79 & 663 & 26 & 22 & 33.1 & -11 \\
\hline Behavioral Ecology & 3.22 & 21 & 54 & 14 & 9 & 57 & 67 & 16 & 19 & 26.9 & -2 \\
\hline Behavioral Ecology \& Sociobiology & 2.75 & 40 & 50 & 15 & 15 & 81 & 51 & 18 & 23 & 33.1 & -3 \\
\hline Biology Letters & 3.35 & 6 & 35 & 10 & 4 & 18 & 29 & 10 & 8 & 25.0 & 0 \\
\hline Current Biology & 9.49 & 13 & 37 & 9 & 5 & 14 & 146 & 32 & 7 & 48.1 & -23 \\
\hline Ecology Letters & 17.95 & 2 & 74 & 37 & 1 & 8 & 137 & 32 & 4 & 20.0 & 5 \\
\hline Ethology & 1.95 & 11 & 37 & 12 & 5 & 30 & 120 & 16 & 12 & 26.8 & -4.5 \\
\hline Evolution & 4.86 & 23 & 103 & 23 & 12 & 65 & 113 & 28 & 28 & 26.1 & -5 \\
\hline J Evolutionary Biology & 3.48 & 17 & 62 & 13 & 9 & 58 & 86 & 21 & 22 & 22.7 & -8 \\
\hline Molecular Ecology & 6.28 & 20 & 90 & 24 & 13 & 62 & 421 & 31 & 27 & 24.4 & -7 \\
\hline Nature & 38.6 & 6 & 142 & 57 & 4 & 7 & 261 & 119 & 7 & 46.2 & -62 \\
\hline Proc Nat Acad Sci USA & 9.74 & 7 & 106 & 35 & 6 & 10 & 128 & 42 & 8 & 41.2 & -7 \\
\hline Proc Royal Society B & 5.68 & 37 & 106 & 39 & 24 & 83 & 128 & 32 & 33 & 30.8 & 7 \\
\hline Science & 31.03 & 2 & 122 & 48 & 3 & 6 & 148 & 61 & 6 & 25.0 & -13 \\
\hline
\end{tabular}

(Note, Frontiers in Zoology is not included in the survey because no papers are retrieved by the search terms promiscuity or promiscuous, and only two papers were retrieved by the search terms polyandry or polyandrous).

${ }^{1} 2012$ Journal Citation Report ${ }^{\circ}$, ISI Web of Knowledge ${ }^{\mathrm{Tm}}$.

${ }^{2} \mathrm{~h}$-index calculated according to J.E. Hirsch in ISI Web of Knowledge $\mathrm{e}^{\mathrm{T}}$.

${ }^{3}$ Calculated as the number of papers retrieved by the search terms promiscuity or promiscuous, divided by the sum of the number of papers retrieved by the search terms promiscuity, promiscuous and polyandry or polyandrous.

${ }^{4}$ The mean cites per paper retrieved by the search terms promiscuity or promiscuous less the mean cites per paper retrieved by the search terms polyandry or polyandrous. 
refer to frequency only. We highlight this issue by evaluating the patterns of use and misuse in the scientific literature of the word 'promiscuity' to describe female mating strategies.

\section{Use and misuse of promiscuous}

We investigated whether polyandrous females were simultaneously described as promiscuous and exhibiting discriminating mate choice in papers published in a representative journal, Animal Behaviour. Drawing on papers published in the period 2000-2010, we identified those that contained 'promiscuous' (and its associated derivations) in either the abstract or main text. For each paper, we asked to which sex the term was applied (male, female or both), and whether the term was applied in a species in which pre-copulatory female choice had been experimentally demonstrated (either in the article itself or other published papers), or whether the authors inferred or suggested its presence in that species. Female mate choice is typically understood to mean a mating preference for different kinds of males $[7,15,16]$, and is inferred from experiments or field observations showing that females prefer males according to the degree of exaggeration of secondary sexual characteristics e.g. [16-18]. We reduced the likelihood of misinterpretation of each paper by ensuring it was assessed independently by at least two readers. We confined our analysis to the term promiscuous because other descriptors of animal mating behaviour (such as polygynous, polyandrous and polygynandrous) do not make inferences about the nature of mating - whether either sex is discriminating or not - and thus are not at issue.

In total, 39 papers were evaluated (see Table 1). 'Promiscuous' was applied to females in 23 cases, males in 2, and in 14 cases the term was either applied to both sexes or the focal sex was ambiguous (significantly, such ambiguity is impossible with precise language, such as polyandry and polygyny). For papers in which 'promiscuous' was applied to females or both sexes (37 papers), female choice was demonstrated or suggested by the authors themselves in 18 instances, while in 15 cases there was no published evidence of female choice (four cases were excluded as the papers were theoretical reviews or metaanalyses). So, in over half of the instances, promiscuous is evidently used incorrectly, a proportion that is likely to be substantially underestimated: the absence of evidence of female choice in the remaining cases is not evidence that female preferences are absent.

\section{Using promiscuity to titillate the reader?}

Promiscuity as a term to describe animal mating behaviour is undoubtedly anthropomorphic, probably accounting for the frequency of its use, especially amongst the primate literature. The discipline does not tolerate other anthropomorphisms in biological science; for example, the term forced copulation is preferred over rape [22], and infanticide preferred over murder [23]. Promiscuity has pejorative and androcentric connotations [20] and is likely to be emotionally evocative [24], typically saved for the females of the species (Table 1): while polygynous males maximise their fitness by mating at the highest rate, females are described as promiscuous. Perhaps promiscuous is used in titles and abstracts precisely because it is titillating, the notion of indiscriminate mating tapping into latent social taboos.

We explored the potential motivation for and consequences of using the term promiscuous by evaluating the citation metrics for papers retrieved by searches in Web of Knowledge (Thomson Reuters). We selected 15 journals and conducted two searches for each journal, using the terms (i) promiscuous OR promiscuity, and (ii) polyandrous OR polyandry (summarised in Table 2). We make the comparison with polyandry only because our previous analysis indicated that, in the vast majority of cases, promiscuity is used to describe female mating frequency (Table 1). Polygyny is widely understood to mean, based on the Greek etymology, multiple mating by males [24] and thus refers to an entirely different behaviour. Roughly a third of the papers included in the sample were identified by the term promiscuous or promiscuity in the title, abstract or key words. While this proportion ranged from $20-50 \%$ between journals, it was not correlated with the journal's Impact Factor (Figure 1). Nevertheless, the mean number of citations of 'polyandry' papers $(34 \pm 7)$ per journal was marginally greater than that of 'promiscuity' papers ( $26 \pm 4$; Wilcoxon Sign-Rank test: $\mathrm{p}=0.07)$, and the single-publication h-index of 'polyandry' papers (16 \pm 2) was significantly higher than that of 'promiscuity' papers ( $9 \pm 2$; Wilcoxon Sign-Rank test: $\mathrm{p}<0.0001)$ (Table 2). It is not clear whether this reflects an author's publishing

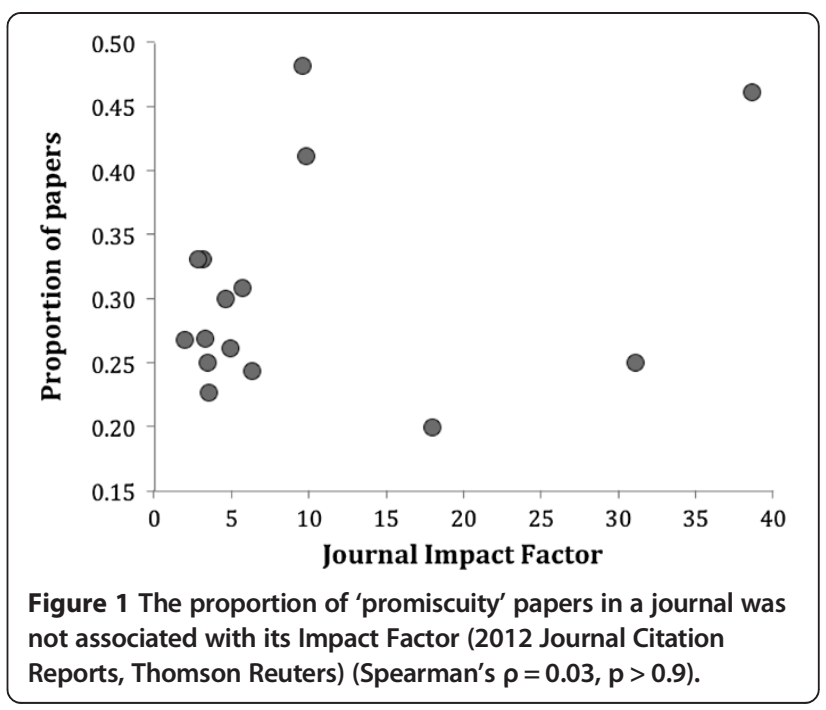


strategy, or that literature searches typically use the term polyandry over promiscuity.

\section{Conclusions}

Arguments over definitions can be tedious, but a cavalier use of borrowed words is unhelpful. Our surveys reveal a tendency to describe female rather than male mating strategies as promiscuous, despite the inherent contradiction in meaning. There was no evidence that journals of different standing publish more or fewer papers that use the term promiscuous, but authors searching for papers using the term promiscuous will generally retrieve lower impact publications.

Promiscuity has become so firmly entrenched in the literature as a synonym for polyandry that its accuracy is no longer questioned. But indiscriminately describing multiple-mating strategies as promiscuous conceals critical features of intriguing evolutionary significance. Indeed, records of truly promiscuous mating strategies, in which females (or males) mated indiscriminately would be remarkable, and predicted, for example, when the costs of mate choice are exorbitant. Like other emotionally evocative terms used to describe sexual behavior [25], promiscuity can be replaced with polyandry, polygyny and polygynandry, as appropriate - descriptive terms that are silent about the nature of mating, and devoid of sociological, psychological and moralistic connotations. Convention is no justification for imprecision, as our survey revealed: without evidence of indiscriminate mating behaviour, 'promiscuity' in evolutionary biology should be left well alone.

\section{Competing interests}

The authors declare that they have no competing interests.

\section{Authors' contributions}

MAE, TMJ and KBM collated and prepared the data; MAE, TMJ and KBM analysed the data; MAE, TMJ and KBM drafted the manuscript. All authors read and approved the final manuscript.

\section{Acknowledgements}

We thank Malin Ah-King, Cordelia Fine, Root Gorelick and an anonymous referee for their insights. The Australian Research Council (DP0558265 to MAE and TMJ; DP0987360 to MAE; and DP110101163 to KBM) and the University of Melbourne (Career Interruption Research Fellowship to TMJ) support our research on the mating behavior of animals.

\section{Author details}

'Department of Zoology, University of Melbourne, Melbourne, VIC 3010, Australia. ${ }^{2}$ Centre for Evolutionary Biology, The University of Western Australia, Crawley 6009, Australia.

Received: 22 October 2013 Accepted: 5 November 2013 Published: 8 November 2013

\section{References}

1. The Shorter Oxford English Dictionary. Oxford: Oxford University Press; 1983.

2. Sala GA: New and Gorgeous Pantomime Entitled Harlequin Prince Cherrytop, etc; 1905. Printed for private distribution.

3. Birdsall DA, Nash D: Occurrence of promiscuity among females in natural populations of deer mice (Peromyscus-maniculatus). Can J Genet Cytol 1972, 14:721.
4. Kushlan JA: Promiscuous mating behavior in white-ibis. Wilson Bulletin 1973, 85:331-332.

5. Merritt RB, Wu BJ: On the Quantification of Promiscuity (Or 'Promyscus' Maniculatus?). Evolution 1975, 29:575-578

6. Harris MP: Promiscuity in the shag as shown by time-lapse photography. Bird Study 1982, 29:149-154.

7. Shuster SM, Wade MJ: Mating Systems and Strategies. New Jersey: Princeton University Press; 2003.

8. Nabours RK: Polyandry in the grouse locust, Paratettix texanus Hancock, with notes on inheritance of acquired characters and telegony. Am Nat 1927, 61:531-538.

9. Bovvee JW: A warning against promiscuous uterine curettage. Surg Gynecol Obstet 1920, 30:618-620

10. Hambourger WE: A study of the promiscuous use of the barbiturates their use in suicides. JAMA 1939, 112:1340-1343.

11. Pickford GD: The influence of continued heavy grazing and of promiscuous burning on spring-fall ranges in Utah. Ecology 1932, 13:159-171.

12. Khersonsky O, Tawfik DS: Enzyme Promiscuity: A Mechanistic and Evolutionary Perspective. Annu Rev Plant Physiol Plant Mol Biol 2010, 79:471-505

13. Raab JR, Kamakaka RT: Insulators and promoters: closer than we think. Nat Rev Genet 2010, 11:439-446.

14. Bird MK, Lawrence AJ: The promiscuous mGlu5 receptor - a range of partners for therapeutic possibilities? Trends Pharmacol Sci 2009, 30:617-623.

15. Darwin C: The Descent of Man, and Selection in relation to Sex. London: John Murray; 1874

16. Andersson M: Sexual Selection. New Jersey: Princeton University Press; 1994.

17. Kirkpatrick M: Good genes and direct selection in evolution of mating preferences. Evolution 1996, 50:2125-2140.

18. Jennions MD, Petrie M: Variation in mate choice and mating preferences: a review of causes and consequences. Biol Rev 1997, 72:283-327.

19. Arnqvist $G$, Nilsson $T$ : The evolution of polyandry: multiple mating and female fitness in insects. Anim Behav 2000, 60:145-164.

20. Olsson M, Shine R, Madsen T, Gullberg A, Tegelström H: Sperm selection by females. Nature 1996, 383:585.

21. Bertram SM, Gorelick R: Quantifying and comparing mating systems using normalized mutual entropy. Anim Behav 2009, 77:201-206.

22. Hilton DFJ: Is it really rape or forced copulation? Bioscience 1982, 32:641.

23. Packer C, Pusey AE: Adaptations of female lions to infanticide by incoming males. Am Nat 1983, 121:716-728.

24. Emlen ST, Oring LW: Ecology, sexual selection, and the evolution of mating systems. Science 1977, 197:215-223.

25. Gowaty P: Sexual terms in sociobiology: emotionally evocative and, paradoxically, jargon. Anim Behav 1982, 30:630-631.

doi:10.1186/1742-9994-10-66

Cite this article as: Elgar et al.: Promiscuous words. Frontiers in Zoology 2013 10:66.

\section{Submit your next manuscript to BioMed Central and take full advantage of:}

- Convenient online submission

- Thorough peer review

- No space constraints or color figure charges

- Immediate publication on acceptance

- Inclusion in PubMed, CAS, Scopus and Google Scholar

- Research which is freely available for redistribution 